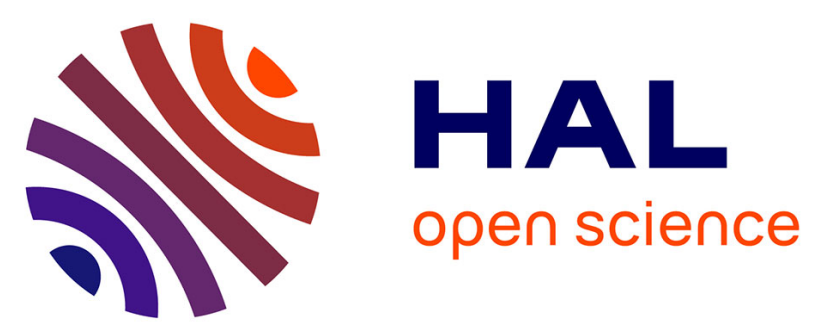

\title{
Leaf-age and soil-plant relationships: key factors for reporting trace-elements hyperaccumulation by plants and design applications
}

Guillaume Losfeld, Laurent L'huillier, Bruno Fogliani, Stéphane Mc Coy, Claude Grison, Tanguy Jaffré

\section{To cite this version:}

Guillaume Losfeld, Laurent L'huillier, Bruno Fogliani, Stéphane Mc Coy, Claude Grison, et al.. Leafage and soil-plant relationships: key factors for reporting trace-elements hyperaccumulation by plants and design applications. Environmental Science and Pollution Research, 2015, Combining Phytoextraction and Ecological Catalysis: an Environmental, Ecological, Ethic and Economic Opportunity, 22 (8), pp.5620 - 5632. 10.1007/s11356-014-3445-z . hal-01937548

\section{HAL Id: hal-01937548 \\ https://hal.umontpellier.fr/hal-01937548}

Submitted on 23 Feb 2021

HAL is a multi-disciplinary open access archive for the deposit and dissemination of scientific research documents, whether they are published or not. The documents may come from teaching and research institutions in France or abroad, or from public or private research centers.
L'archive ouverte pluridisciplinaire HAL, est destinée au dépôt et à la diffusion de documents scientifiques de niveau recherche, publiés ou non, émanant des établissements d'enseignement et de recherche français ou étrangers, des laboratoires publics ou privés. 


\title{
Leaf-age and soil-plant relationships: key factors for reporting trace-elements hyperaccumulation by plants and design applications
}

\author{
Guillaume Losfeld • Laurent L'Huillier • Bruno Fogliani • \\ Stéphane Mc Coy • Claude Grison • Tanguy Jaffré
}

\begin{abstract}
Relationships between the trace-elements (TE) content of plants and associated soil have been widely investigated especially to understand the ecology of TE hyperaccumulating species to develop applications using TE phytoextraction. Many studies have focused on the possibility of quantifying the soil TE fraction available to plants, and used bioconcentration (BC) as a measure of the plants ability to absorb TE. However, BC only offers a static view of the dynamic phenomenon of TE accumulation. Accumulation kinetics are required to fully account for TE distributions in plants. They are also crucial to design applications where maximum TE concentrations in plant leaves are needed. This paper provides a review of studies of BC (i.e. soil-plant relationships) and leaf-age in relation to $\mathrm{TE}$ hyperaccumulation. The paper focuses of $\mathrm{Ni}$ and $\mathrm{Mn}$ accumulators and hyperaccumulators from New Caledonia who were previously overlooked until recent Ecocatalysis applications
\end{abstract}

G. Losfeld · C. Grison $(\bowtie)$

FRE 3673-Bioinspired chemistry and ecological innovation-CNRS, University of Montpellier 2, Stratoz-Cap Alpha, Avenue de l'Europe, 34830 Clapiers, France

e-mail: claude.grison@cnrs.fr

L. L'Huillier · B. Fogliani

Institut Agronomique néo-Calédonien (IAC), « Diversités biologique et fonctionnelle des écosystèmes terrestres », 98890 Païta, New Caledonia

S. M. Coy

Service préservation de l'environnement, Vale Nouvelle-Calédonie,

52 avenue Foch, BP218, 98845 Noumea, New Caledonia

T. Jaffré

UMR AMAP, IRD-Institut de recherche pour le développement, Laboratoire de Botanique et d'Ecologie Végétale Appliquées, 98848 Noumea, New Caledonia

e-mail: tanguy.jaffre@ird.fr emerged for such species. Updated data on Mn hyperaccumulators and accumulators from New Caledonia are also presented and advocate further investigation of the hyperaccumulation of this element. Results show that leaf-age should be considered in the design of sample collection and allowed the reclassification of Grevillea meisneri known previously as a $\mathrm{Mn}$ accumulator to a Mn hyperaccumulator

Keywords Hyperaccumulation · Phytoextraction · Bioconcentration $\cdot$ Leaf-age $\cdot$ Nickel $\cdot$ Manganese

\section{Introduction}

The discovery of Ni concentrations ranging from 1.8 to $4.7 \%$ in the dry leaves of Psychotria gabriellae (ex. Psychotria douarrei), a Rubiaceae endemic to New Caledonia (Jaffré and Schmid 1974), led to the emergence of the concept of Ni hyperaccumulation (Jaffre et al. 1976). Such concentrations are comparable to those in ores currently exploited for $\mathrm{Ni}$ production in New Caledonia: an average $2.5 \% \mathrm{Ni}$ in saprolites, and $1.7 \% \mathrm{Ni}$ in low-grade limonites (DIMENC 2008). Potentially economic applications were quickly considered as species accumulating other metals such as $\mathrm{Au}, \mathrm{Cu}$, or $\mathrm{Zn}$ were also discovered in other countries (Baker et al. 1988). Phytoextraction was developed industrially for phytomining (Brooks et al. 1998; Chaney et al. 2007) and phytoremediation to decontaminate soils containing high concentrations of trace-elements (TE) (Cunningham and Berti 1993; McGrath and Zhao 2003). Yet both probably failed to meet the expectations initially raised (Ernst 2000; Ernst 2005; van der Ent et al. 2013b).

Ecocatalysis has emerged as a new Green Chemistry approach (Escande et al. 2014a, b), with a high potential for the valuation of TE-rich biomass (Hunt et al. 2014). The TE-rich biomass obtained from these metallophytes can be directly 
used as reagents or catalysts in organic chemical reactions (Grison and Escande 2013a, b; Losfeld et al. 2012c). Ecocatalysis provides the first perspective of enhancing the unique TE-rich biomass from New Caledonia (and elsewhere) and promoting a new field in Green Chemistry (Escande et al. 2014a, b). The first results showed that polymetallic ecocatalysts could perform better and provide much higher selectivity than classical homogeneous and heterogeneous catalysts (Losfeld et al. 2012a, b). The development of this new concept is creating paradigm shifts in phytoextraction and Green Chemistry because leaves from $\mathrm{Ni}$ and $\mathrm{Mn}$ hyperaccumulators or accumulators have become new efficient and eco-friendly catalytic systems (Escande et al. 2013; Thillier et al. 2013).

The development of such applications spurred massive research efforts for understanding the hyperaccumulation of TE by plants. Cutting-edge techniques allow for in-vivo localisation of some elements, e.g. Cd (Hu et al. 2013) or Mn (Fernando et al. 2013), and a precise determination of TE speciation in plants, e.g. $\mathrm{Ni}$ (Callahan et al. 2012, 2008) or Mn (Fernando et al. 2010). Molecular and genetic mechanisms underlying TE accumulation are also thoroughly investigated (Verbruggen et al. 2009) for this purpose New Caledonia may well prove a place of major interest because of its flora (Jaffre et al. 2013; Merlot et al. 2014). Yet apparently more simple questions remain elusive: why do plants accumulate TE (Boyd 2013)? What are the biogeochemical processes at work in the rhizosphere (Alford et al. 2010)? The latter is particularly crucial to design applications, where yields (phytomining) or efficiency (phytoremediation by way of phytoextraction) are determined by soil-plant relationships. Bioconcentration (BC), the ratio of a TE concentration in plant to that in soil has often been used as a measure of the ability of plants to take up a TE (Morrison et al. 1980; Zhao et al. 2003).

This paper aims to discuss the relevance of this approach as TE hyperaccumulation is also a dynamic phenomenon with kinetic factors. Ni and Mn hyperaccumulators or accumulators endemic to the metallophyte hotspot (Whiting et al. 2004) of New Caledonia are the main focus of this paper, as few tropical evergreen species have been examined. The development of Ecocatalysis requires the assessment of the possibilities of these species. Considering leaf-age (a proxy for accumulation kinetics) in the design of sample collection allowed the reclassification of Grevillea meisneri (previously known as a $\mathrm{Mn}$ accumulator) as Mn hyperaccumulator. It also provides insights on leaves harvest design for maximum TE concentrations that are required for potential applications. Updated data on Mn hyperaccumulators and accumulators from New Caledonia are also presented and advocate further investigation on the hyperaccumulation of this element.

TE hyperaccumulation: what and why?

The term 'hyperaccumulator' was coined by Jaffre et al. (1976) in a report of the extraordinary ability of New
Caledonian species Pycnandra acuminata (ex. Sebertia acuminata) to accumulate $\mathrm{Ni}$ in its tissues. The term hyperaccumulator was generally used to describe plant species containing Ni over $1,000 \mathrm{mg} \cdot \mathrm{kg}^{-1}$ on a dry-weight basis in their aerial tissues. Thirteen Ni hyperaccumulators from New Caledonia, Italy and Australia were known in the 1970s (Jaffre et al. 1976). Reeves (1992) then clarified the definition of Ni hyperaccumulation: a species may be considered a $\mathrm{Ni}$ hyperaccumulator if a concentration of $\mathrm{Ni}$ above $1,000 \mathrm{mg} \cdot \mathrm{kg}^{-1}$ has been reported in the dry leaves of at least one specimen growing in its natural habitat. Furthermore, active uptake only should be considered, from soil to leaves through roots and sap. Direct deposition of soil particle on leaves should be taken care of as a potential perturbation on measurements (Faucon et al. 2007). TE hyperaccumulation was recently reviewed (van der Ent et al. 2013a) and can be defined in a similar manner for various other elements, with specific thresholds for each $100 \mathrm{mg} \cdot \mathrm{kg}^{-1}$ for $\mathrm{Cd}$, Se and $\mathrm{Tl}$; $300 \mathrm{mg} \cdot \mathrm{kg}^{-1}$ for $\mathrm{Co}, \mathrm{Cu}$ and $\mathrm{Cr} ; 1,000 \mathrm{mg} \cdot \mathrm{kg}^{-1}$ for $\mathrm{Ni}, \mathrm{Pb}$ and As and 3,000 mg. $\mathrm{kg}^{-1}$ for $\mathrm{Zn}$. In the case of Mn, this threshold is set at 10,000 mg.kg ${ }^{-1}$.

By now, $450 \mathrm{Ni}$ hyperaccumulators have been reported throughout the world (van der Ent et al. 2013a) and New Caledonia is definitely a metallophyte hotspot, with $65 \mathrm{Ni}$ hyperaccumulating species (Jaffre et al. 2013). Only Cuba, where $135 \mathrm{Ni}$ hyperaccumulators have been found, is more diverse than New Caledonia (Reeves 2003). Although dismissed by van der Ent et al. (2013a), studies of the flora of New Caledonia have led to the use of a dedicated terminology. For some species, e.g. P. acuminata (Jaffre et al. 1976) or P. gabriellae (Jaffré and Schmid 1974), Ni concentrations above $1 \%$ in the dry leaves of some individuals were observed in their natural environment. This is one order of magnitude greater than the 'hyperaccumulation' threshold, and such species are referred to as 'hypernickelophore' (Jaffré and Schmid 1974). So far, 17 such species have been reported in New Caledonia (Table 1).

The "raison d'être" for TE hyperaccumulation remains largely elusive with various hypotheses brought out (Boyd and Martens 1992) and two major hypotheses investigated:

1. According to the defensive enhancement hypothesis (Boyd 2012), TE hyperaccumulation evolved as it provided hyperaccumulators with stronger defences against herbivores or pathogens. Accumulation of more than one TE and complex formation with organic compounds could also result in further improved defence, referred to as 'the joint effect' by Boyd (2012).

2. 'The interference hypothesis', or elemental allelopathy (Baker and Brooks 1989; Boyd 2004; Boyd and Martens 1998), suggests TE-enriched litter under hyperaccumulators, e.g. P. acuminata (Boyd and Jaffre 2001), would exert a selective pressure on soil micro- 
Table 1 Hypernickelophore species from New Caledonia adapted from Jaffre et al. (2013)

\begin{tabular}{llll}
\hline Family & Genus & Species & Max Ni level (\%) \\
\hline Cunoniaceae & Geissois & bradfordii & 1.3 \\
& & lanceolata & 2.3 \\
Phyllantaceae & Phyllanthus & barainosa & 1.5 \\
& & favieri & 1.5 \\
& & lucilae & 4.2 \\
& & memaoyaensis & 3.4 \\
& & parangoyensis & 2.7 \\
Rubiaceae & Gynochthodes & to be identified & 1.5 \\
& Psychotria & gabriellae & 6.4 \\
Salicaceae & Homalium & francii & 1.5 \\
& & guillainii & 1.2 \\
& & kanaliense & 1.2 \\
Sapotaceae & Pycnandra & acuminata & 2.6 \\
Violaceae & Hybanthus & austrocaledonicus & 2.6 \\
& & caledonicus & 1.8 \\
\hline
\end{tabular}

organisms, and also prevent other non-adapted plant species from settling. However, TE hyperaccumulation does not always result in TE-enriched litters, as exemplified by P. gabriellae (Boyd et al. 1999). Limits to this hypothesis were recently reviewed, with many studies found to present unclear conclusions (Morris et al. 2009). An improved understanding of soil-plant relationships could possibly clarify the scope of this hypothesis.

Recent efforts to understand TE speciation (Callahan et al. 2012, 2008; Fernando et al. 2010; Grison et al. 2013), their location in plants (Fernando et al. 2013, 2008), as well as genetic and molecular factors involved in TE hyperaccumulation could shed new light on how TE hyperaccumulation evolved. However assessing costs and benefits of this trait remain difficult (Boyd 2013). At present, the question why TE hyperaccumulation evolved remains elusive.

\section{Models for soil-plants relationships}

Initial studies of bioconcentration

Figure 1a adapted from Baker (1981) frequently appears when dealing with the ecology of TE hyperaccumulators. It is based on using $\mathrm{Ni}$-spiked soil to observe the respective responses of various Alyssum species to $\mathrm{Ni}$ exposure (Morrison et al. 1980). Figure 1a can also be represented in terms of bioconcentration (BC) (Fig. 1b). $\mathrm{BC}$ for an element $\mathrm{X}$ is defined as a measure of the ability of plants to take up a TE:

$C(X)=\frac{\text { Concentration of } X \text { in dry leaves }}{\text { Total concentration of } X \text { in soil }}$

The measure of total elemental concentrations in soil can be performed using acid digestions and gives reliable results regardless of the method (Sauve et al. 2000). Such methods were used in studies by Morrison et al. (1980).

TE hyperaccumulators are usually expected to display high BC (Baker 1981; van der Ent et al. 2013a) because of their ability to accumulate TE at high concentrations in their leaves, regardless of respective concentrations in soil (Assuncao et al. 2003; Bert et al. 2002). However, in certain circumstances evident in Fig. 1b, BC is expected to decrease at high soil TE concentrations. This effect was described not only for $\mathrm{Ni}$ hyperaccumulating Alyssum species (Morrison et al. 1980), but also for Zn hyperaccumulator Noccaea caerulescens, which also belongs to the Brassicaceae family (Zhao et al. 2003). In the case of $N$. caerulescens, a detailed meta-analysis showed $\mathrm{BC}$ to vary by over 3 orders of magnitude as a function of soil total $\mathrm{Zn}$ concentration. Soil total $\mathrm{Zn}$ concentrations could explain $82 \%$ of the observed variance in a power law relationship. $\mathrm{Zn}$ transporters saturation, or uptake regulation were mentioned as potential causes for the decrease in BC at high soil concentrations (Pence et al. 2000). However, $\mathrm{BC}$ cannot be considered a simple function of total elemental concentrations in soil because the actual availability of TE is also of interest, as it may vary regardless of total concentrations in soil (Diesing et al. 2008; Ross 1994).

Total versus available concentrations

Design applications for TE hyperaccumulating species were a major motive for developing measurements describing the soil TE fractions that are available to plants. They determine not only the possibility of phytoremediation by way of phytoextraction (Koopmans et al. 2008; Robinson 1997) but also potential yields of phytomining operations ( $\mathrm{Li}$ et al. 2003; Robinson et al. 1999). Nevertheless, accurate quantification of the soil TE fractions available to plants is technically difficult (Young et al. 2005; Zhang and Young 2005) and was performed using various methods without a general agreement on the results (Feng et al. 2005; Robinson 1997; Sauve et al. 2000).

Available TE in soils from New Caledonia were generally studied using diethylene triamine pentaacetic acid (DTPA) extractions (Becquer et al. 1995; L'Huillier 1996), adapted from the methods developed by Lindsay and Norvell (1978). It proved useful for agricultural purposes mainly (L'Huillier and Edighoffer 1996; Lhuillier et al. 1996). Ion-exchange resins were introduced later (Becquer et al. 2002) providing 
Fig. 1 Different plant responses to soil trace-elements adapted from Baker (1981) a in terms of leaves concentration and $\mathbf{b}$ in terms of bioconcentration factor
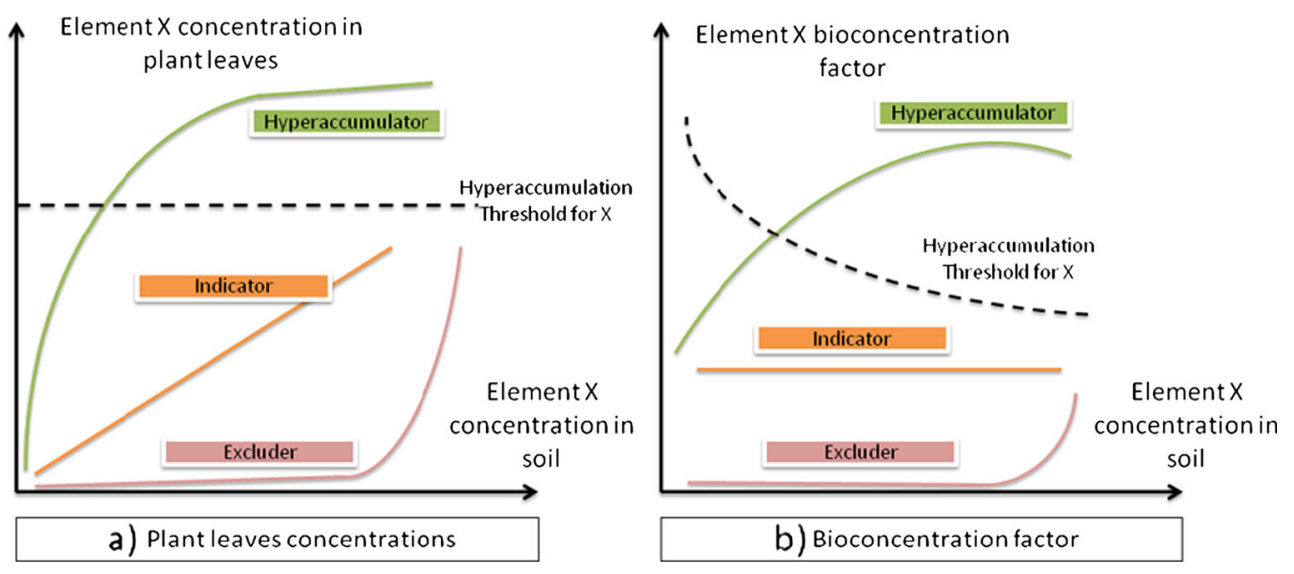

improved results for five species that were not $\mathrm{Ni}$ or $\mathrm{Mn}$ hyperaccumulators or accumulators. In-depth studies of soil may provide increased insights (Diesing et al. 2008), but are not readily applicable. Numerous physical parameters, such as bulk density, compactness, water holding capacity, as well as chemical parameters including elemental speciation, $\mathrm{pH}$, Eh and oxygen availability are significant components of soil properties (Ernst 1996). Moreover, active processes are involved in the accumulation of TE by plants, as shown in studies of their rhizosphere (Alford et al. 2010).

\section{Nickel hyperaccumulators from New Caledonia}

There are few comprehensive studies of soil-plant relationships concerning nickel hyperaccumulators from New Caledonia. Initial studies of Ni hyperaccumulation by P. gabriellae and Hybanthus austrocaledonicus nonetheless provide meaningful soil-plant data (Jaffré and Schmid 1974). In this study, total $\mathrm{Ni}$ concentrations were used to characterise soil at each sampling station, whilst Ni concentrations in leaves were measured in an average individual for each station, i.e. leaves from several individuals in each station were analysed as a single sample. In spite of small sample sizes $(n=5)$, results for H. austrocaledonicus (Fig. 2a) show significant relationships $(P<0.05)$ : soil total Ni concentrations may explain $88 \%$ of the variance observed in $\mathrm{BC}$ in a power law relationship. Regression coefficients are of the same order of magnitudes as those found by Zhao et al. (2003) for $N$. caerulescens, and the questions of whether it originates from similar biological mechanisms could be of interest. This relationship was confirmed later by Lee et al. (1977). The case of P. gabriellae (Fig. 2b) is also meaningful as $75 \%$ of the variance observed in $\mathrm{BC}$ can be explained by the logarithm of soil total Ni concentration $(P<0.001)$. Thus, according to these initial studies (Jaffré and Schmid 1974; Lee et al. 1977), it would not be irrelevant to consider total soil concentration for a single element when studying its hyperaccumulation by plants. Yet using these data, it was not possible to highlight significant relationships between leaf $\mathrm{Ni}$ and soil total $\mathrm{Ni}$ concentrations.

First investigations of the relationships between soil Ni assessed by DTPA extraction and the Ni concentrations in the dry leaves of Ni hyperaccumulators focused on Homalium kanaliense and $H$. austrocaledonicus. Performed at the individual level, they showed significant relationships for both species (Lee et al. 1977). Subsequent studies focused on P. gabriellae using a similar approach, but were inconclusive
Fig. 2 Soil-plant relationships for Ni hyperaccumulating species a Hybanthus austrocaledonicus $\mathbf{b}$ Psychotria gabriellae a) Hybanthus austrocaledonicus

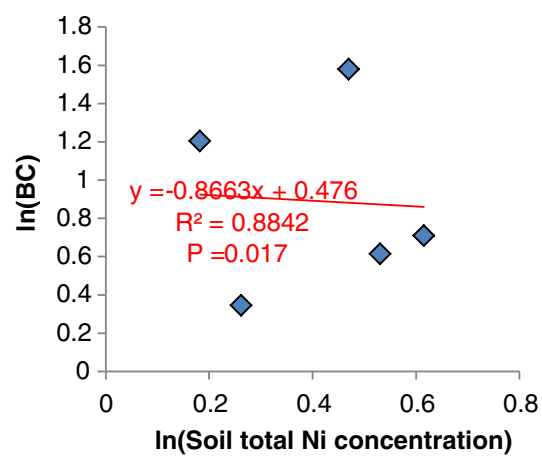

b) Psychotria gabriellae

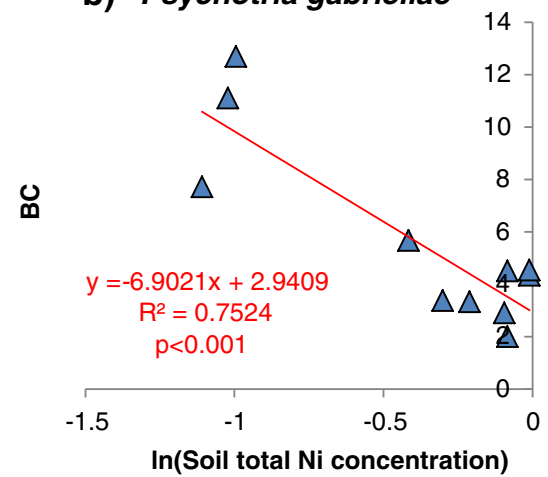


(Boyd et al. 1999). A major difference with the previous study by Jaffré and Schmid (1974) was that all analyses were performed at the individual level. The hypothesis tested was also different. Jaffré and Schmid (1974) investigated the response of plant to the soil on which they grow, whilst Boyd et al. (1999) were investigating the influence of Ni-rich leaves litter on soil. This may result in differences in soil sampling depth. Using the latter approach for P. acuminata led to conclusive results; a significantly higher Ni concentration (DTPA) was observed in soil under the canopy of $P$. acuminata compared to that under non-hyperaccumulating trees (Boyd and Jaffre 2001). However, correlation is not causal and whether $P$. acuminata preferentially established on Ni-rich soil or enriched soil in $\mathrm{Ni}$ was not resolved. More recently, Amir et al. (2007) worked at the species level and confirmed significant relationships between soil Ni measured by DTPA extraction and leaves Ni concentrations for Geissois pruinosa, Geissois hirsuta, H. kanaliense, H. austrocaledonicus, Phyllanthus favieri, P. gabriellae and $P$. acuminata. They also found significant correlations at the individual levels within species G. pruinosa, P. favieri and $P$. gabriellae but not $P$. acuminata. Large sample sizes in the study by Amir et al. (2007) ensured the statistical reliability of the tests performed.

Finally, the broader picture that can be drawn from the literature on Ni hyperaccumulators from New Caledonia clearly shows that current models using soil-plant relationships are not fully satisfactory, regardless of the method used to assess Ni concentrations in soil. A considerable limit also lies within the different volumes of soil roots actually explore which is larger for shrubs or trees such as $\mathrm{Ni}$ hyperaccumulators from New Caledonia than for Alyssum species or $N$. caerulescens.

\section{Manganese hyperaccumulation}

Species hyperaccumulating and accumulating manganese

New Caledonia has long been recognised as a metallophyte hotspot for its Ni hyperaccumulators: these were recently reviewed (Jaffre et al. 2013) and species such as $P$. gabriellae or P. acuminata remain emblematic for their extraordinary abilities to concentrate and tolerate Ni (Jaffre et al. 1976; Jaffré and Schmid 1974). Yet there are also detailed records of Mn hyperaccumulation: Alyxia poyaensis (ex. Alyxia rubricaulis) and Denhamia (ex. Maytenus) species were reported to accumulate $\mathrm{Mn}$ at concentrations above $1 \%$ in their dry leaves (Jaffré 1977). Such species were termed 'hypermanganesophore' by Jaffré (1977) but this denomination has now been replaced by 'Mn hyperaccumulator', according to the definition by van der Ent et al. (2013a). In a similar way, numerous species from New Caledonia accumulate manganese at levels ranging from 3,000 to 10,000 mg. $\mathrm{kg}^{-1}$ (Jaffré 1977, 1979, 1980). Although less remarkable than hyperaccumulators and dismissed by van der Ent et al. (2013a), they were classified as manganese accumulators (Jaffré 1980).

\section{Acknowledged manganese hyperaccumulators}

Table 2 presents an updated review of acknowledged Mn hyperaccumulators after Fernando et al. (2013). Species Phytolacca americana (Min et al. 2007; Pollard et al. 2009), Polygonum hydropiper (Wang et al. 2008; Yang et al. 2013) and Schima superba (Yang et al. 2008) were excluded from Table 2 as records of manganese concentrations above $10,000 \mathrm{mg} \cdot \mathrm{kg}^{-1}$ in natural conditions are not published. Similarly, an unidentified Eugenia species was reported as a Mn hyperaccumulator (Proctor et al. 1989) and could be included when further evidence is available. As regards $\mathrm{Mn}$ hyperaccumulators from New Caledonia, the following additions were made:

1. Latest taxonomic revisions are included:

a. A. poyaensis is no longer a subspecies of A. rubricaulis but a new Mn hyperaccumulator. Latest data from Jaffré indicate Mn concentrations up to $1.4 \%$ in the dry leaves of this species.

b. Various Maytenus species were reported to be Mn hyperaccumulators (Jaffré 1977). They now belong to the Denhamia genus with a single species, Denhamia fournieri occurring as two subspecies, drakeana and fournieri (Fernando et al. 2008). The subspecies drakeana was shown to hyperaccumulate Mn by Fernando et al. (2008). Older results considering species other than Maytenus drakeana are relevant for assessing the Mn accumulation ability of D. fournieri ssp. fournieri. Thus, reports of Mn concentrations up to $3.3 \%$ in the dry leaves of D. fournieri ssp. fournieri are still valid (Jaffré 1977)

c. Eugenia clusoides now belongs to the Gossia genus and the Mn hyperaccumulator described by Jaffré (1980) is Gossia clusoides ssp. ploumensis.

d. Macadamia species from New Caledonia now belong to the Virotia genus.

2. New data on Mn hyperaccumulation are presented:

a. Gossia diversifolia is reported for the first time to hyperaccumulate $\mathrm{Mn}$ with concentrations in the dry leaves up to $1.8 \%$

b. Polyscias pancheri reported as a $\mathrm{Mn}$ accumulator (Enright et al. 2001) is as a new Mn hyperaccumulator, which highlights the interest of the Araliaceae family with other reports of $\mathrm{Mn}$ 
Table 2 Mn hyperaccumulators updated from Fernando et al. (2013)

\begin{tabular}{|c|c|c|c|c|c|}
\hline Family & Genus & Species & Max Mn level (\%) & Location & Reference \\
\hline Apocynaceae & Alyxia & poyaensis & 1.4 & New Caledonia & This study \\
\hline \multirow[t]{2}{*}{ Araliaceae } & Chengiopanax & sciadophylloides & 2.4 & Japan & Mizuno et al. 2008 \\
\hline & Polyscias & pancheri & 1.4 & New Caledonia & This study \\
\hline \multirow[t]{3}{*}{ Celastraceae } & \multirow[t]{3}{*}{ Denhamia } & cunninghamii & 2.5 & Australia & Fernando et al. 2013 \\
\hline & & fournieri ssp. drakeana & $2.0^{*}$ & New Caledonia & Fernando et al. 2008 \\
\hline & & fournieri ssp. fournieri & 3.3 & New Caledonia & Jaffré 1977 \\
\hline Clusiaceae & Garcinia & amplexicaulis & 1.2 & New Caledonia & Jaffré 1980 \\
\hline \multirow[t]{9}{*}{ Myrtaceae } & \multirow[t]{9}{*}{ Gossia } & bamagensis & 4.0 & Australia & Fernando et al. 2013 \\
\hline & & bidwillii & 1.9 & Australia & Bidwell et al. 2002 \\
\hline & & clusioides var. ploumensis & 1.0 & New Caledonia & Jaffré 1980 \\
\hline & & diversifolia & 1.8 & New Caledonia & this study \\
\hline & & fragrantissima & 3.5 & Australia & Fernando et al. 2013 \\
\hline & & gonoclada & 1.5 & Australia & Fernando et al. 2013 \\
\hline & & lucida & 1.5 & Australia & Fernando et al. 2013 \\
\hline & & sankowskiorum & 3.0 & Australia & Fernando et al. 2013 \\
\hline & & shepherdii & 1.5 & Australia & Fernando et al. 2013 \\
\hline Phytolaccaceae & Phytolacca & acinosa & 1.9 & China & Xue et al. 2004 \\
\hline Polygonacea & Polygonum & pubescens & 1.6 & China & Deng et al. 2010 \\
\hline \multirow[t]{4}{*}{ Proteaceae } & Beaupreopsis & paniculata & 1.2 & New Caledonia & Jaffré 1979 \\
\hline & Grevillea & meisneri & 1.1 & New Caledonia & This study \\
\hline & Virotia & angustifolia & 1.2 & New Caledonia & Jaffré 1979 \\
\hline & (ex Macadamia) & neurophylla & 5.5 & New Caledonia & Jaffré 1979 \\
\hline
\end{tabular}

$*=$ average values

hyperaccumulation in Chengiopanax sciadophylloides from Japan.

c. G. meisneri, previously known to accumulate $\mathrm{Mn}$ at concentrations ranging from 450 to $4,500 \mathrm{mg} \cdot \mathrm{kg}^{-1}$ was found to hyperaccumulate $\mathrm{Mn}$.

Finally, there are currently 22 acknowledged $\mathrm{Mn}$ hyperaccumulators, 11 of them originating from New Caledonia and 8 from Australia.

\section{Interest of manganese accumulators}

Table 3 gathers the latest data available on Mn accumulators from New Caledonia. Such species are of interest because in spite of Mn concentrations under the hyperaccumulation threshold, they can provide an interesting starting material for Ecocatalysis that can be directly used as green oxidant reagents and catalysts in organic chemical reactions. The ecocatalysts derived from $\mathrm{Mn}$ accumulators, called Eco$\mathrm{Mn}$, allow the development of the first substitute reagents to oxidants forbidden in the European Union by the REACH regulation. They are also interesting because further sampling efforts could probably lead to the discovery (or reclassification) of new $\mathrm{Mn}$ hyperaccumulators as was the case for G. meisneri. Revising existing data concerning $\mathrm{Mn}$ accumulators raised the following comments:

1. According to unpublished data from Jaffré, Apiopetalum glabratum should be considered a Mn accumulator as it showed Mn concentrations up to $5,300 \mathrm{mg} \cdot \mathrm{kg}^{-1}$ in its dry leaves. It is also the case for an unidentified Styphelia species.

2. Latest taxonomic revision of the Alyxia genus led to the description of 10 synonyms. However, existing data on their Mn accumulation ability (Brooks et al. 1981) are difficult to re-use. Thus, this genus would require a thorough revision. Existing data from the literature are nonetheless presented.

3. In a similar way, species of the Polyscias genus other than P. pancheri were identified to accumulate high levels of Mn which suggest Polyscias dioca and Polyscias jaffrei merit further investigation of interest.

Finally, there are currently 24 species from New Caledonia that were observed to accumulate $\mathrm{Mn}$ at concentrations above $3,000 \mathrm{mg} \cdot \mathrm{kg}^{-1}$ (yet under $10,000 \mathrm{mg} \cdot \mathrm{kg}^{-1}$ ) in the dry leaves of at least one individual. In addition to be potentially $\mathrm{Mn}$ 
Table 3 Mn accumulators from New Caledonia updated from Jaffré (1980)

\begin{tabular}{|c|c|c|c|c|}
\hline Family & Genus & Species & Max Mn level (mg.kg-1) & Reference \\
\hline Apiaceae & Apiopetalum & glabratum & 5,300 & This study \\
\hline \multirow[t]{6}{*}{ Apocynaceae } & \multirow[t]{6}{*}{ Alyxia } & baillonii & $6,630^{*}$ & Jaffré 1980 \\
\hline & & caletioides & 9,400 & Jaffré 1980 \\
\hline & & coriaceae & 4,500 & Jaffré 1980 \\
\hline & & leucogyne & 5,250 & Jaffré 1980 \\
\hline & & sarasinii & $5,000^{*}$ & Jaffré 1980 \\
\hline & & tisserantii & 4,875 & Jaffré 1980 \\
\hline Casuarinaceae & Gymnostoma & intermedium & 4,180 & Jaffré et al. 1994 \\
\hline \multirow[t]{3}{*}{ Cunoniaceae } & \multirow[t]{3}{*}{ Pancheria } & confusa & 4,500 & Jaffré 1980 \\
\hline & & hirsuta & 5,000 & Jaffré 1980 \\
\hline & & billardieri & 6,500 & Jaffré 1980 \\
\hline Eriacaceae & Styphelia & & 4,000 & This study \\
\hline Loganiaceae & Geniostoma & densiflorum ssp. oleifolium & 7,250 & Jaffré 1980 \\
\hline Picrodendraceae & Austrobuxus & rubiginosus & 4,125 & Jaffré 1980 \\
\hline \multirow[t]{7}{*}{ Proteaceae } & \multirow[t]{2}{*}{ Beauprea } & gracilis & 3,000 & Jaffré 1979 \\
\hline & & montana & $3,625^{*}$ & Jaffré 1979 \\
\hline & \multirow[t]{3}{*}{ Grevillea } & exul ssp. exul & 3,900 & Jaffré 1979 \\
\hline & & exul ssp. rubiginosa & 6,200 & Jaffré 1979 \\
\hline & & gillivrayi & 8,200 & Jaffré 1979 \\
\hline & Virotia & francii & 5,480 & Jaffré 1979 \\
\hline & Stenocarpus & milnei & 3,900 & Jaffré 1979 \\
\hline Santalaceae & Exocarpos & neocaledonicus & 4,750 & Jaffré 1980 \\
\hline Sapindaceae & Guioa & glauca & 4,500 & Jaffré 1980 \\
\hline Violaceae & Hybanthus & caledonicus & 7,750 & Jaffré 1980 \\
\hline
\end{tabular}

$*=$ average values

hyperaccumulators, such species also showed interesting responses toward aluminium (Jaffré 1979, 1980). Proteoid or cluster roots found in the Proteaceae family are also subject to extensive investigation (Lamont 2003), and highlight the interest of considering active processes at work in the rhizosphere of TE hyperaccumulators (Alford et al. 2010).

\section{Soil-plant relationships}

Noccaea caerulescens is often considered a model species to study Zn hyperaccumulation (Peer et al. 2003). Yet in the case of Mn hyperaccumulators, there is no such species available and existing datasets are far less comprehensive. It must be noted that many hyperaccumulating species were discovered in the last decade (see Tables 2 and 3), whilst $\mathrm{Zn}$ and Ni hyperaccumulators have been studied for at least 35 years now (Jaffre et al. 1976; Reeves and Brooks 1983). The following observations gathered in Table 4 are nonetheless possible:

1. Phytolacca acinosa (Xue et al. 2004), P. americana (Min et al. 2007) and Polygonum pubescens (Deng et al. 2010) display low $\mathrm{BC}$ with mean values at $0.18,0.06$ and 0.12 , respectively. For these species, foliar manganese concentrations increase with soil total manganese concentrations, whilst BC decreases. However no significant correlations could be highlighted from the available data, except in the case of $P$. pubescens where $\mathrm{BC}$ was significantly related to soil total Mn concentrations in a power law relationship. In this case, more than $90 \%$ of the variance in $\mathrm{BC}$ can be explained by soil total Mn.

2. All Mn hyperaccumulators from New Caledonia except Garcinia amplexicaulis show average BC above 1.5 and it is also the case of Australian species Gossia bidwillii. Yet there are also larger variations in $\mathrm{BC}$, especially in the case of $G$. diversifolia. In all cases except for G. amplexicaulis, BC decreases with increasing soil total Mn concentrations. Variations in BC can be significantly related to variations in total $\mathrm{Mn}$ concentration in soil for A. poyaensis, G. meisneri and P. pancheri but without a unified model applicable.

3. In most cases, leaf Mn concentrations can be explained by soil total Mn concentrations. Relationships are significant except for G. meisneri and P. pancheri (and Mn hyperaccumulators from China). However, there is no 


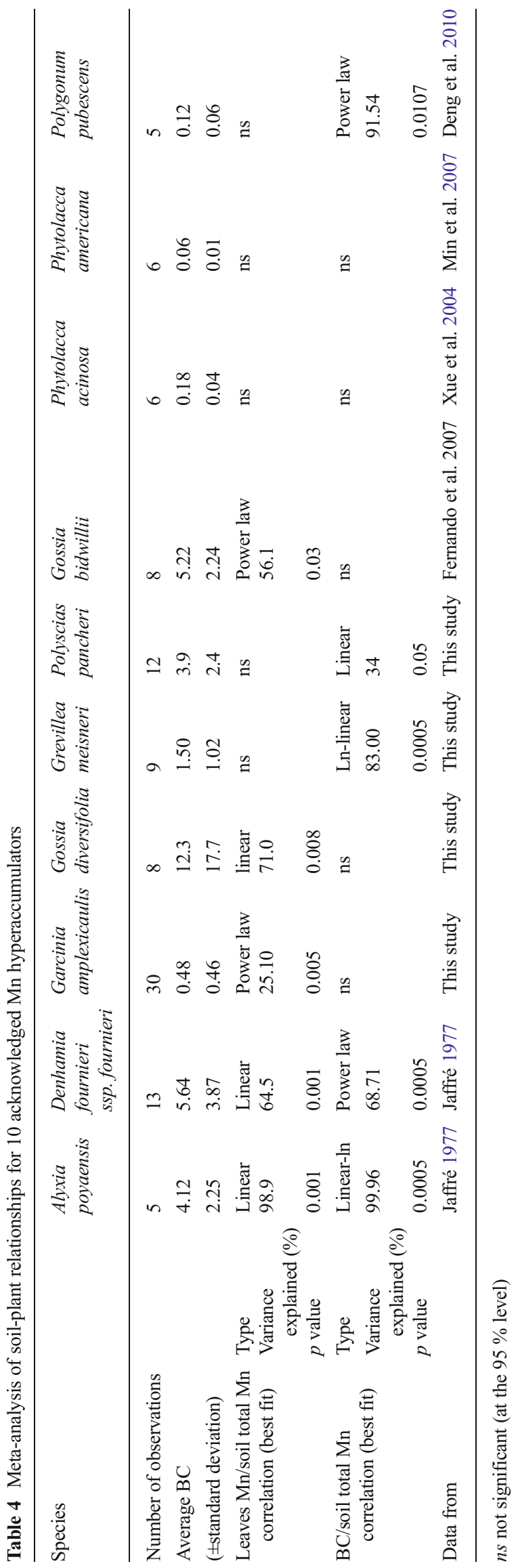

unique model that may account for the mechanism of Mn hyperaccumulation, possibly because of different responses at the species level, or because of differences in other soil parameters.

The major difference that can be highlighted from these data is a bimodal response of species to soil of natural origins, e.g. in New Caledonia or Australia, or soil disturbed by mining for Mn, e.g. in China. Taking into account currently available data, it appears difficult to find a single reliable model for soil-plant relationships in the case of $\mathrm{Mn}$ hyperaccumulators. Restrictions emphasised for $\mathrm{Ni}$ hyperaccumulators are also valid for Mn whose chemistry is more complex than Ni or Zn.

\section{Leaf-age effects and their implications for designing applications}

Leaf-age effects on the elemental composition of plant tissues

Another reason why the study of soil-plant relationships brings little advance in understanding TE hyperaccumulation in general is because TE accumulation is a dynamic phenomenon: early reports of Ni hyperaccumulation by Alyssum species highlighted a quick phenomenon, where maximum concentrations in plant leaves were reached within 5 days after exposure to Ni-spiked soil (Morrison et al. 1980). The first report of a significant effect of plant aging was made much later studying $\mathrm{Ni}$ hyperaccumulation in Streptanthus species (Kruckeberg and Reeves 1995). Similar observations concerning Ni hyperaccumulators were made for Alyssum pintodasilvae from Portugal (deVarennes et al. 1996), for Berkheya species from South Africa (Boyd et al. 2004; Robinson et al. 2003b), and for P. gabriellae (Boyd et al. 1999; Davis et al. 2001), H. kanaliense and G. pruinosa (Boyd and Jaffre 2009) in New Caledonia. Interestingly, other $\mathrm{Ni}$ hyperaccumulators such as Agatea longipedcillata, Caesaria silvana, Homalium guillainii, $H$. austrocaledonicus and P. acuminata did not show significant leaf-age effects (Boyd and Jaffre 2009). As regards hyperaccumulators of other elements, significant leaf-age effects were observed for the Japanese Mn hyperaccumulator C. sciadophylloides (Mizuno et al. 2008), the Chinese As hyperaccumulator Pteris vtitata (Gonzaga et al. 2007) as well as various $\mathrm{Zn}$ hyperaccumulators (Macnair and Smirnoff 1999; Robinson et al. 1998).

Recent data were obtained by collecting G. meisneri (Fig. 3) leaves in the 'Creek à Paul' valley near the Tiébaghi massive, New Caledonia $\left(20^{\circ} 29^{\prime} 35.03^{\prime \prime} \mathrm{S}, 164^{\circ} 12^{\prime} 22.76^{\prime \prime}\right.$ E). Leaf sampling was performed as follows. A qualitative assessment of leaf-age was performed according to the position of leaves on stems and visual assessment of their colours. The collected leaves 


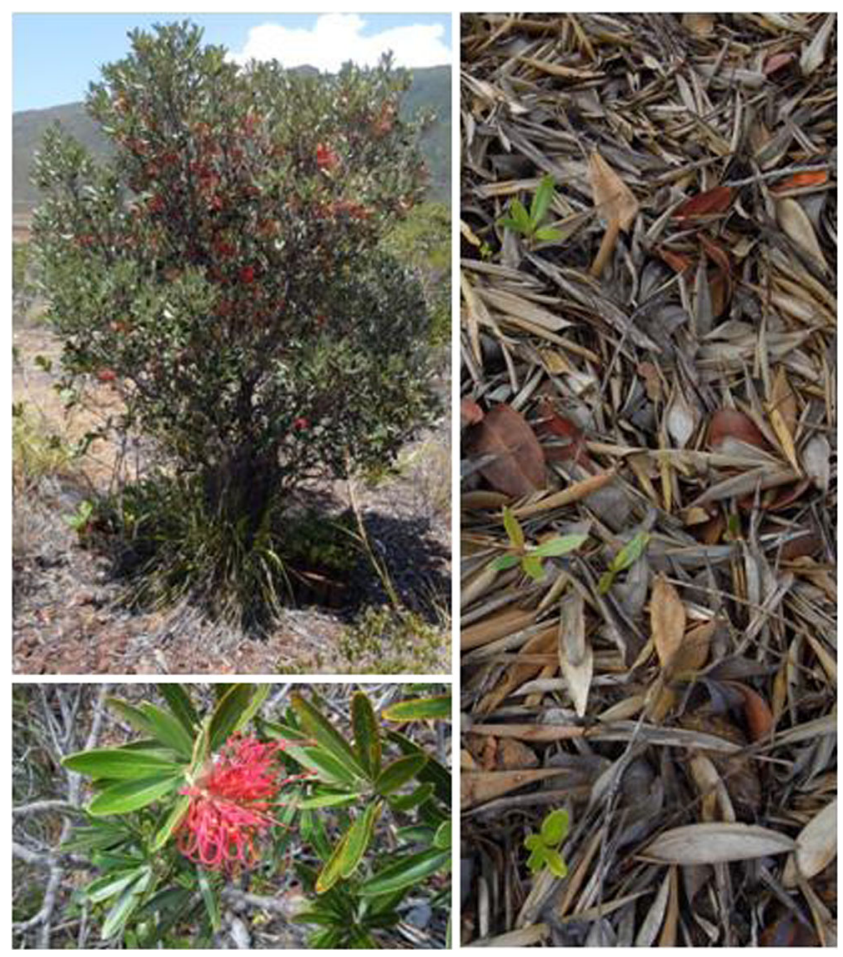

Fig. 3 Grevillea meisneri, Creek à Paul, New Caledonia and litter under Grevillea meisneri including young plants

were separated in two age-categories, i.e. 'young leaves' and 'mature leaves'. Approximately $500 \mathrm{~g}$ of fresh leaves per age-category was collected on each individual sampled, to ensure the reliability of the concentrations measured. Litter composed of dry fallen leaves was also collected under each tree as it was readily accessible. The results obtained are gathered in Fig. 4 and show a significant difference between young leaves (YL) and older leaves (OL). Litter composed of fallen G. meisneri leaves show intermediate Mn concentrations, but they are not statistically different from young leaves or old leaves. Concentrations up to $1.1 \%$ of $\mathrm{Mn}$

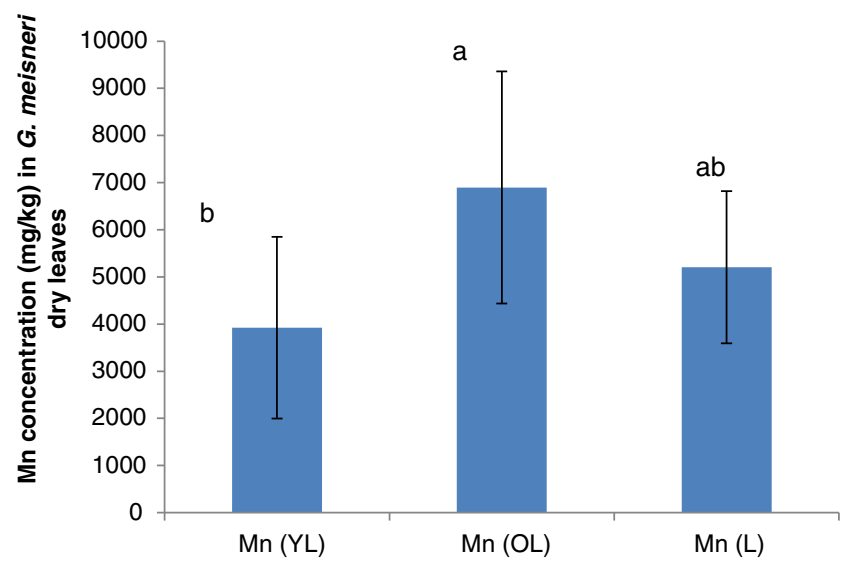

Fig. 4 Incidence of leaf-age on the Mn concentrations $(\mathrm{mg} / \mathrm{kg})$ in Grevillea meisneri leaves were found in old G. meisneri leaves, which make this species a new Mn hyperaccumulator. Similar trends were also observed for Grevillea exul (Fig. 5) growing at the 'Camp des Sapins' mine, Thio, New Caledonia. Lower Mn concentrations in $G$. exul are also possibly related to plant age (3.5 years in this case). This shows the necessity of considering leaf-age when assessing the ability to accumulate TE of a plant species and also advocates further investigation of $\mathrm{Mn}$ accumulating species from New Caledonia.

Implications for designing applications

\section{Usual applications}

Potential applications are generally referred to as TE phytoextraction, which is the extraction of TE from soil by plants (Robinson 1997). Two different approaches for phytoextraction can be distinguished, both termed by Cunningham and Berti (1993) but devised earlier (Baker et al. 1988):

1. Phytoremediation by way of TE phytoextraction addresses the issue of TE contaminated soil and aimed to provide a way to clean them.

2. Phytomining, initially termed 'biomining' (Cunningham and Berti 1993), refers to the use of plants, usually TE hyperaccumulators, to produce bio-ores subsequently used in metal production (Brooks et al. 1998).

Deemed unrealistic in a first instance (Baker et al. 1988), phytomining probably raised the greatest expectations. It was developed for nickel to an industrial level using Alyssum species. Usual pyrometallurgical processes (Chaney et al. 2007), or other chemical separation techniques (Barbaroux et al. 2012) can be used to recover nickel. Phytoremediation by way of phytoextraction on the other hand appeared more convincing (Baker et al. 1988): yet it raised more questions than it actually solved. Feasibility and cost-effectiveness are

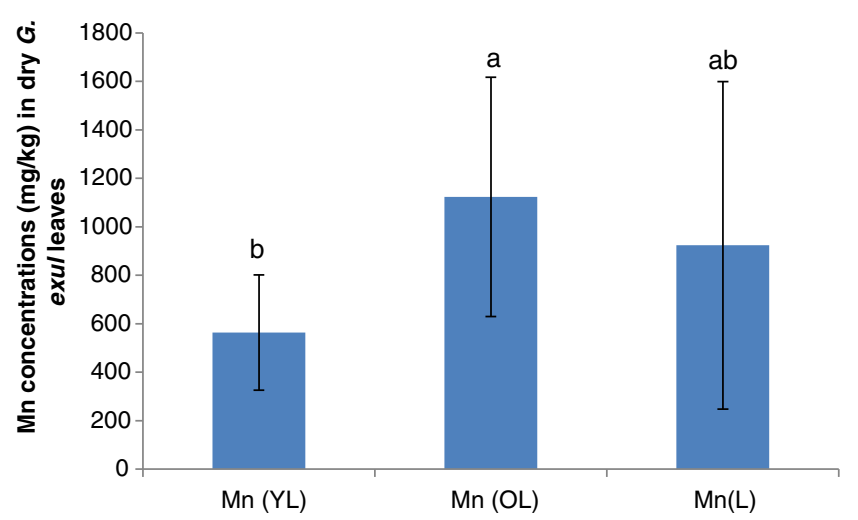

Fig. 5 Incidence of leaf-age on the Mn concentrations $(\mathrm{mg} / \mathrm{kg})$ in Grevillea exul leaves 
still questioned (Conesa and Schulin 2010; Ernst 2005; Robinson et al. 2003a), as well as the issue of contaminatedbiomass disposal (Ernst 2000; Sas-Nowosielska et al. 2004).

However, in both cases ecological principles should guide action and site-specific approaches using local species:

1. May avoid poor results, e.g. using Alyssum species in Indonesia (van der Ent et al. 2013b)

2. May avoid the emergence of invasive species, e.g. Alyssum species in the USA, as reported by the Oregon Department of Agriculture (2014)

3. Is a way to promote the conservation of metallophyte species (Whiting et al. 2004)

\section{Ecocatalysis}

The emerging concept of Ecocatalysis may also use TE-rich biomass from phytoremediation by way of phytoextraction (Losfeld et al. 2012a) as well as from phytomining (Escande et al. 2014a, b; Losfeld et al. 2012b; Thillier et al. 2013) and was covered by various patents (Grison and Escande 2013a, 2013b). It leads to original (unusual oxydation states, new associated chemical species) and effective catalysts and reagents. Ecocatalysis offers a unique opportunity of cooperative catalysis, where the synergetic action of diverse TE presents a huge potential. Activities, chemo-, stereo-selectivity and recyclability of ecocatalysts are higher than classical catalysts in various reactions. This is conceptually very different from phytomining and phytoremediation by way of phytoextraction and could overcome the limits of these technologies. Ecocatalysis specifically tackles TE-rich biomass regardless of the metal considered, and it is fully compliant with the end use of metals obtained, i.e. Green Chemistry, thus allowing greener and broader perspectives for present environmental and socio-economic challenges.

\section{Developing applications}

Considering Mn hyperaccumulators, e.g. G. meisneri or Mn accumulators, e.g. G. exul as potential sources of Mn for application in Ecocatalysis requires the design of leaf harvesting schemes. Taking into account their lower Mn concentration, lower biomass and potential plant stress, collecting young leaves would probably be unproductive. Older leaves show the highest Mn concentration and thus could be considered of utmost interest. However, their collection would also result in plant stress and species from New Caledonia are known to grow slowly. Moreover, the age parameter was assessed on a qualitative basis, and it would be quite difficult to implement a collection based on such a qualitative parameter. The most practical proposal is then to focus on litters: they have an intermediate $\mathrm{Mn}$ concentration and although litter biomass would need to be measured precisely to assess yield, it is certain that this option would ensure sustainable yields, compared to the two others.

Various metallophyte species (e.g. Geissois spp., Grevillea spp., Phyllanthus spp.) proved useful for the reclamation of mining areas in New Caledonia. The development of new outlets, e.g. Ecocatalysis could provide supplementary revenues for the restoration of such areas. Developing reclamation schemes for highly degraded quarries or spoils storage areas using metal hyperaccumulators along with Cyperaceae and other soil-improving species could provide an efficient way to control watershed erosion of degraded land. Generating alternative incomes through the promotion of metal-rich biomass used in organic chemistry could not only cover the cost of the revegetation operation but also generate post revegetation economic activities for New Caledonia as well as other mining countries.

\section{Conclusion}

From this review and from the new data presented, it clearly appears that usual soil-plant studies of TE hyperaccumulation based on measuring TE concentrations in soil to assess $\mathrm{BC}$ are limited. Although useful for the study of $\mathrm{Zn}$ or $\mathrm{Ni}$ hyperaccumulators from the Brassicaceae family, they are far from conclusive when applied to $\mathrm{Ni}$ or $\mathrm{Mn}$ hyperaccumulators from New Caledonia. Some trends may be highlighted but contradictory results are possible and no general model emerges from this study. This is partly due to issues in measuring soil TE concentrations:

1. Total concentrations are easily measured but do not reflect soil chemistry, and the amount of a TE that is actually available to a plant is different from that assessed by acid digestions. Soils from New Caledonia were studied using DTPA extractions as a way to assess TE availability, with a main focus on $\mathrm{Ni}$ and $\mathrm{Mn}$. However, although useful for agricultural purposes, the method failed to account for $\mathrm{Ni}$ or Mn hyperaccumulators response to soil TE concentrations.

2. The volume of the rhizosphere of $\mathrm{Ni}$ or $\mathrm{Mn}$ hyperaccumulating shrubs or trees from New Caledonia is larger than that of Brassicaceae resulting in difficulty in assessing rhizosphere properties, including $\mathrm{TE}$ concentrations.

Investigating G. meisneri and G. exul with Ecocatalysis applications in mind allowed to highlight temporal patterns in Mn accumulation for these species: young leaves contained significantly less $\mathrm{Mn}$ than older leaves. This is useful to design applications, but also allowed to reclassify G. meisneri as a 
hyperaccumulator of Mn. Latest data on Mn hyperaccumulators are also presented, and New Caledonia is clearly a hotspot for Mn hyperaccumulation. Various Mn accumulators from the island could be investigated further taking into account leaf-age, which would probably lead to the discovery of new Mn hyperaccumulators and revision of their current accumulation status. The development of Ecocatalysis applications for Mn-rich biomass could spur massive research efforts for understanding $\mathrm{Mn}$ hyperaccumulation by plants. It should also encourage the development of integrative studies of Mn hyperaccumulation, as is the case for $\mathrm{Ni}$ or other TE.

Acknowledgments Financial support from the 'Agence Nationale pour la Recherche' (ANR 11ECOT01101), Société Le Nickel (SLN) and Ecole Polytechnique, Paris Tech (PhD studentship) is gratefully acknowledged. Sample collection was possible with the consent of Province Nord and Province Sud of New Caledonia.

\section{References}

Alford ER, Pilon-Smits EAH, Paschke MW (2010) Metallophytes-a view from the rhizosphere. Plant Soil 337:33-50. doi:10.1007/ s11104-010-0482-3

Amir H, Perrier N, Rigault F, Jaffre T (2007) Relationships between Nihyperaccumulation and mycorrhizal status of different endemic plant species from New Caledonian ultramafic soils. Plant Soil 293:23-35. doi:10.1007/s11104-007-9238-0

Assuncao AGL, Bookum WM, Nelissen HJM, Vooijs R, Schat H, Ernst WHO (2003) Differential metal-specific tolerance and accumulation patterns among Thlaspi caerulescens populations originating from different soil types. New Phytol 159:411-419. doi:10.1046/j.14698137.2003.00819.x

Baker AJM (1981) Accumulators and excluders - strategies in the response of plants to heavy-metals. J Plant Nutr 3:643-654. doi:10. 1080/01904168109362867

Baker AJM, Brooks RR (1989) Terrestrial higher plants which hyperaccumulate metallic elements - a review of their distribution, ecology and phytochemistry. Biorecovery 1:81-126

Baker A, Brooks R, Reeves R (1988) Growing for gold... and copper... and zinc. New Sci 116:44-48

Barbaroux R, Plasari E, Mercier G, Simonnot MO, Morel JL, Blais JF (2012) A new process for nickel ammonium disulfate production from ash of the hyperaccumulating plant Alyssum murale. Sci Total Environ 423:111-119. doi:10.1016/j.scitotenv.2012.01.063

Becquer T, Bourdon E, Pétard J (1995) Disponibilité du nickel le long d'une toposéquence de sols développés sur roches ultramafiques de Nouvelle-Calédonie. C R Acad Sci 321:585-592

Becquer T, Rigault F, Jaffre T (2002) Nickel bioavailability assessed by ion exchange resin in the field. Commun Soil Sci Plant Anal 33: 439-450. doi:10.1081/css-120002755

Bert V, Bonnin I, Saumitou-Laprade P, de Laguerie P, Petit D (2002) Do Arabidopsis halleri from nonmetallicolous populations accumulate zinc and cadmium more effectively than those from metallicolous populations? New Phytol 155:47-57. doi:10.1046/j.1469-8137. 2002.00432.x

Bidwell SD, Woodrow IE, Batianoff GN, Sommer-Knudsen J (2002) Hyperaccumulation of manganese in the rainforest tree Austromyrtus bidwillii (Myrtaceae) from Queensland, Australia. Funct Plant Biol 29:899-905. doi:10.1071/pp 01192
Boyd RS (2004) Ecology of metal hyperaccumulation. New Phytol 162: 563-567. doi:10.1111/j.1469-8137.2004.01079.x

Boyd RS (2012) Plant defense using toxic inorganic ions: conceptual models of the defensive enhancement and joint effects hypotheses. Plant Sci 195:88-95. doi:10.1016/j.plantsci.2012.06.012

Boyd RS (2013) Exploring tradeoffs in hyperaccumulator ecology and evolution. New Phytol 199:871-872. doi:10.1111/nph.12398

Boyd RS, Jaffre T (2001) Phytoenrichment of soil Ni content by Sebertia acuminata in New Caledonia and the concept of elemental allelopathy. S Afr J Sci 97:535-538

Boyd RS, Jaffre T (2009) Elemental concentrations of eleven New Caledonian plant species from serpentine soils: elemental correlations and leaf-age effects. Northeast Nat 16:93-110. doi:10.1656/ 045.016.0508

Boyd RS, Martens SN (1992) The Raison d'Etre for metal hyperaccumulation by plants The vegetation of ultramafic (Serpentine) soils:279-289

Boyd RS, Martens SN (1998) The significance of metal hyperaccumulation for biotic interactions. Chemoecology 8:1-7. doi:10.1007/s000490050002

Boyd RS, Jaffre T, Odom JW (1999) Variation in nickel content in the nickel-hyperaccumulating shrub Psychotria douarrei (Rubiaceae) from New Caledonia. Biotropica 31:403-410. doi:10.1111/j.17447429.1999.tb00382.x

Boyd RS, Davis MA, Balkwill K (2004) Nickel accumulation patterns in two South African Ni hyperaccumulator species Ultramafic rocks: their soils, vegetation and fauna Proceedings of the Fourth International Conference on Serpentine Ecology, Cuba, 21-26 April, 2003 275-278

Brooks RR, Trow JM, Veillon JM, Jaffre T (1981) Studies on manganese accumulating Alyxia species from New Caledonia. Taxon 30:420 423. doi: $10.2307 / 1220141$

Brooks RR, Chambers MF, Nicks LJ, Robinson BH (1998) Phytomining Trends Plant Sci 3:359-362. doi:10.1016/s1360-1385(98)01283-7

Callahan DL et al (2008) LC-MS and GC-MS metabolite profiling of nickel(II) complexes in the latex of the nickelhyperaccumulating tree Sebertia acuminata and identification of methylated aldaric acid as a new nickel(II) ligand. Phytochemistry 69:240-251

Callahan DL, Roessner U, Dumontet V, De Livera AM, Doronila A, Baker AJM, Kolev SD (2012) Elemental and metabolite profiling of nickel hyperaccumulators from New Caledonia. Phytochemistry 81:80-89. doi:10.1016/j.phytochem.2012.06. 010

Chaney RL, Angle JS, Broadhurst CL, Peters CA, Tappero RV, Sparks DL (2007) Improved understanding of hyperaccumulation yields commercial phytoextraction and phytomining technologies. J Environ Qual 36:1429-1443. doi:10.2134/jeq2006.0514

Conesa HM, Schulin R (2010) The Cartagena-La Union mining district (SE spain): a review of environmental problems and emerging phytoremediation solutions after fifteen years research. J Environ Monit 12:1225-1233

Cunningham SD, Berti WR (1993) Remediation of contaminated soils with green plants - an overview. In Vitro Cell Dev Biol-Plant 29P: 207-212

Davis MA, Pritchard SG, Boyd RS, Prior SA (2001) Developmental and induced responses of nickel-based and organic defences of the nickel-hyperaccumulating shrub, Psychotria douarrei. New Phytol 150:49-58. doi:10.1046/j.1469-8137.2001.00067.x

Deng H, Li MS, Chen YX, Luo YP, Yu FM (2010) A new discovered manganese hyperaccumulator-Polygonum pubescens Blume. Fresenius Environ Bull 19:94-99

deVarennes A, Torres MO, Coutinho JF, Rocha M, Neto M (1996) Effects of heavy metals on the growth and mineral composition of a nickel hyperaccumulator. J Plant Nutr 19:669-676. doi:10.1080/ 01904169609365151 
Diesing WE et al (2008) Zinc speciation and isotopic exchangeability in soils polluted with heavy metals. Eur J Soil Sci 59:716-729. doi:10. $1111 /$ j.1365-2389.2008.01032.x

DIMENC (2008) Le schéma de mise en valeur des richesses minières de la Nouvelle-Calédonie

Enright NJ, Rigg L, Jaffre T (2001) Environmental controls on species composition along a (maquis) shrubland to forest gradient on ultramafics at Mont Do, New Caledonia. S Afr J Sci 97:573-580

Ernst WHO (1996) Bioavailability of heavy metals and decontamination of soils by plants. Appl Geochem 11 doi:10.1016/0883-2927(95)00040-2

Ernst WHO (2000) Evolution of metal hyperaccumulation and phytoremediation hype. New Phytol 146:357-358. doi:10.1046/j. 1469-8137.2000.00669.x

Ernst WHO (2005) Phytoextraction of mine wastes - options and impossibilities. Chem Erde-Geochem 65:29-42. doi:10.1016/j.chemer. 2005.06.001

Escande V, Olszewski TK, Grison C (2013) Preparation of ecological catalysts derived from $\mathrm{Zn}$ hyperaccumulating plants and their catalytic activity in Diels-Alder reaction Comptes Rendus Chimie

Escande V et al (2014a) Ecological catalysis and phytoextraction: symbiosis for future. Appl Catal B-Environ 146:279-288. doi:10.1016/j. apcatb.2013.04.011

Escande V, Tomasz O, Eddy P, Grison C (2014b) Biosourced polymetallic catalysts: an efficient means to synthesize underexploited platform molecules from carbohydrates. Chem Sus Chem. doi: $10.1002 / \mathrm{cssc} .201400078$

Faucon MP, Shutcha MN, Meerts P (2007) Revisiting copper and cobalt concentrations in supposed hyperaccumulators from SC Africa: influence of washing and metal concentrations in soil. Plant Soil 301:29-36. doi:10.1007/s11104-007-9405-3

Feng MH, Shan XQ, Zhang SZ, Wen B (2005) A comparison of the rhizosphere-based method with DTPA, EDTA, $\mathrm{CaCl} 2$, and $\mathrm{NaNO} 3$ extraction methods for prediction of bioavailability of metals in soil to barley. Environ Pollut 137:231-240

Fernando DR, Woodrow IE, Jaffre T, Dumontet V, Marshall AT, Baker AJM (2008) Foliar manganese accumulation by Maytenus founieri (Celastraceae) in its native New Caledonian habitats: populational variation and localization by X-ray microanalysis. New Phytol 177: 178-185. doi:10.1111/j.1469-8137.2007.02253.x

Fernando DR, Mizuno T, Woodrow IE, Baker AJM, Collins RN (2010) Characterization of foliar manganese (Mn) in $\mathrm{Mn}$ (hyper)accumulators using X-ray absorption spectroscopy. New Phytol 188:1014-1027

Fernando DR, Marshall A, Baker AJM, Mizuno T (2013) Microbeam methodologies as powerful tools in manganese hyperaccumulation research: present status and future directions. Front Plant Sci 4:319. doi:10.3389/fpls.2013.00319

Gonzaga MIS, Ma LQ, Santos JAG (2007) Effects of plant age on arsenic hyperaccumulation by Pteris vittata 1 . Water Air Soil Pollut 186: 289-295. doi:10.1007/s11270-007-9485-y

Grison C, Escande V (2013a) Use of certain manganese-accumulating plants for carrying out organic chemistry reactions. WO2014016509-A1

Grison C, Escande V (2013b) Use of certain metal-accumulating plants for implementing organic chemistry reactions. WO $2013150197 \mathrm{~A} 1$

Grison C, Escande V, Petit E, Garoux L, Boulanger C, Grison C (2013) Psychotria douarrei and Geissois pruinosa, novel resources for the plant-based catalytic chemistry. RSC Adv 3:22340-22345. doi:10. 1039/c3ra43995j

$\mathrm{Hu} \mathrm{PJ}$ et al (2013) Nitrate facilitates cadmium uptake, transport and accumulation in the hyperaccumulator Sedum plumbizincicola. Environ Sci Pollut Res 20:6306-6316

Hunt AJ et al (2014) Phytoextraction as a tool for green chemistry. Green Process Synth 3:3-22

Jaffré T (1977) Accumulation du manganèse par des espèces associées aux terrains ultrabasiques. C R Acad Sci Paris 284:1573-1575
Jaffré T (1979) Accumulation du manganèse par les proteacées de Nouvelle-Calédonie. C R Acad Sci Paris 285:425-428

Jaffré T (1980) Etude écologique du peuplement végétal des sols dérivés de roches ultrabasiques en Nouvelle Calédonie vol 124. Travaux et documents. ORSTOM, Paris

Jaffré T, Schmid M (1974) Accumulation de nickel par une rubiacée de Nouvelle-Calédonie, Psychotria douarrei (G. Beauvisage) Däniker Compte Rendus de l'Académie des Sciences, Paris Série D:17271730

Jaffre T, Brooks RR, Lee J, Reeves RD (1976) Sebertia acuminata: a hyperaccumulator of nickel from New Caledonia. Science 193:579 580. doi:10.1126/science.193.4253.579

Jaffré T, Gauthier D, Rigault F, McCoy S (1994) Les casuarinacées endémiques Bois et forêts des tropiques:4

Jaffre T, Pillon Y, Thomine S, Merlot S (2013) The metal hyperaccumulators from New Caledonia can broaden our understanding of nickel accumulation in plants. Front Plant Sci 4:279. doi: 10.3389/fpls.2013.00279

Koopmans GF, Roemkens PFAM, Fokkema MJ, Song J, Luo YM, Japenga J, Zhao FJ (2008) Feasibility of phytoextraction to remediate cadmium and zinc contaminated soils. Environ Pollut 156. doi: 10.1016/j.envpol.2008.05.029

Kruckeberg AR, Reeves RD (1995) Nickel accumulation by serpentine species of Streptanthus (Brassicaceae): field and greenhouse studies. Madrono 42:458-469

L'Huillier L (1996) Biodisponibilité du nickel dans les sols ferrallitiques ferritiques de Nouvelle-Calédonie. Effets toxiques de Ni sur le développement et la physiologie du maïs

L'Huillier L, Edighoffer S (1996) Extractability of nickel and its concentration in cultivated plants in Ni rich ultramafic soils of New Caledonia. Plant Soil 186:255-264. doi:10.1007/bf02415521

Lamont BB (2003) Structure, ecology and physiology of root clusters-a review. Plant Soil 248:1-19

Lee J, Brooks RR, Reeves RD, Boswell CR, Jaffre T (1977) Plant-soil relationships in a New Caledonian serpentine flora. Plant Soil 46: 675-680. doi:10.1007/bf00015930

Lhuillier L, dAuzac J, Durand M, MichaudFerriere N (1996) Nickel effects on two maize (Zea mays) cultivars: growth, structure, $\mathrm{Ni}$ concentration, and localization. Can J Bot-Rev Can Bot 74:15471554

Li YM et al (2003) Development of a technology for commercial phytoextraction of nickel: economic and technical considerations. Plant Soil 249:107-115. doi:10.1023/a:1022527330401

Lindsay W, Norvell WA (1978) Development of a DTPA soil test for zinc, iron, manganese, and copper. Soil Sci Soc Am J 42:421-428

Losfeld G, de la Blache PV, Escande V, Grison C (2012a) Zinc hyperaccumulating plants as renewable resources for the chlorination process of alcohols. Green Chem Lett Rev 5 doi:10.1080/ 17518253.2012 .667157

Losfeld G, Escande V, de La Blache PV, L'Huillier L, Grison C (2012b) Design and performance of supported Lewis acid catalysts derived from metal contaminated biomass for Friedel-Crafts alkylation and acylation. Catal Today 189 doi:10.1016/j.cattod.2012.02.044

Losfeld G, Escande V, Jaffre T, L'Huillier L, Grison C (2012c) The chemical exploitation of nickel phytoextraction: an environmental, ecologic and economic opportunity for New Caledonia. Chemosphere 89:907-910

Macnair MR, Smirnoff N (1999) Use of zincon to study uptake and accumulation of zinc by zinc tolerant and hyperaccumulating plants. Commun Soil Sci Plant Anal 30:1127-1136. doi:10.1080/ 00103629909370273

McGrath SP, Zhao FJ (2003) Phytoextraction of metals and metalloids from contaminated soils. Curr Opin Biotechnol 14:277-282. doi:10. 1016/s0958-1669(03)00060-0

Merlot S, Hannibal L, Martins S, Martinelli L, Amir H, Lebrun M, Thomine S (2014) The metal transporter PgIREG1 from the 
hyperaccumulator Psychotria gabriellae is a candidate gene for nickel tolerance and accumulation. J Exp Bot:eru025

Min Y, Tie B, Tang M, Aoyama I (2007) Accumulation and uptake of manganese in a hyperaccumulator Phytolacca Americana. Miner Eng 20:188-190. doi:10.1016/j.mineng.2006.06.003

Mizuno T, Asahina R, Hosono A, Tanaka A, Senoo K, Obata H (2008) Age-dependent manganese hyperaccumulation in Chengiopanax sciadophylloides (Araliaceae). J Plant Nutr 31:1811-1819. doi:10. 1080/01904160802325396

Morris C, Grossl PR, Call CA (2009) Elemental allelopathy: processes, progress, and pitfalls. Plant Ecol 202:1-11

Morrison RS, Brooks RR, Reeves RD (1980) Nickel uptake by Alyssum species. Plant Sci Lett 17:451-457. doi:10.1016/0304-4211(80) 90132-7

Oregon Department of Agriculture (2014) ODA Plant Programs, Noxious Weed Control yellow tuft (Alyssum murale, A. corsicum). http://www. oregon.gov/ODA/PLANT/WEEDS/pages/weed_yellowtuft.aspx

Peer WA, Mamoudian M, Lahner B, Reeves RD, Murphy AS, Salt DE (2003) Identifying model metal hyperaccumulating plants: germplasm analysis of 20 Brassicaceae accessions from a wide geographical area. New Phytol 159:421-430

Pence NS et al (2000) The molecular physiology of heavy metal transport in the $\mathrm{Zn} / \mathrm{Cd}$ hyperaccumulator Thlaspi caerulescens. Proc Natl Acad Sci U S A 97:4956-4960. doi:10.1073/pnas.97.9.4956

Pollard AJ, Stewart HL, Roberson CB (2009) Manganese hyperaccumulation in phytolacca americana L. from the Southeastern United States. Northeast Nat 16:155-162

Proctor J, Phillipps C, Duff GK, Heaney A, Robertson FM (1989) Ecological studies on Gunung Silam, a small ultrabasic mountain in Sabah, Malaysia. II. Some forest processes. J Ecol 77:317-331. doi: $10.2307 / 2260752$

Reeves RD (1992) The hyperaccumulation of nickel by serpentine plants The vegetation of ultramafic (Serpentine) Soils:253-277

Reeves RD (2003) Tropical hyperaccumulators of metals and their potential for phytoextraction. Plant Soil 249:57-65. doi:10.1023/ a: 1022572517197

Reeves R, Brooks R (1983) Hyperaccumulation of lead and zinc by two metallophytes from mining areas of Central Europe Environmental pollution series A. Ecol Biol 31:277-285

Robinson BH (1997) The phytoextraction of heavy-metals from metalliferous soils. Massey University

Robinson BH, Leblanc M, Petit D, Brooks RR, Kirkman JH, Gregg PEH (1998) The potential of Thlaspi caerulescens for phytoremediation of contaminated soils. Plant Soil 203:47-56. doi:10.1023/ a: 1004328816645

Robinson BH, Brooks RR, Gregg PEH, Kirkman JH (1999) The nickel phytoextraction potential of some ultramafic soils as determined by sequential extraction. Geoderma 87:293-304. doi:10.1016/s00167061(98)00062-7

Robinson B, Fernandez JE, Madejon P, Maranon T, Murillo JM, Green S, Clothier B (2003a) Phytoextraction: an assessment of biogeochemical and economic viability. Plant Soil 249:117-125. doi:10.1023/ a: 1022586524971

Robinson BH, Lombi E, Zhao FJ, McGrath SP (2003b) Uptake and distribution of nickel and other metals in the hyperaccumulator Berkheya coddii. New Phytol 158:279-285. doi:10.1046/j.14698137.2003.00743.x
Ross SM (1994) Toxic metals in soil-plant systems. John Wiley \& Sons Ltd

Sas-Nowosielska A, Kucharski R, Malkowski E, Pogrzeba M, Kuperberg JM, Krynski K (2004) Phytoextraction crop disposal — an unsolved problem. Environ Pollut 128:373-379. doi:10.1016/j.envpol.2003. 09.012

Sauve S, Hendershot W, Allen HE (2000) Solid-solution partitioning of metals in contaminated soils: dependence on $\mathrm{pH}$, total metal burden, and organic matter. Environ Sci Technol 34:1125-1131. doi:10. 1021/es9907764

Thillier Y, Losfeld G, Escande V, Dupouy C, Vasseur J-J, Debart F, Grison C (2013) Metallophyte wastes and polymetallic catalysis: a promising combination in green chemistry. The illustrative synthesis of 5 '-capped RNA. Rsc Adv 3:5204-5212. doi:10.1039/ c3ra23115a

van der Ent A, Baker AJM, Reeves RD, Pollard AJ, Schat H (2013a) Hyperaccumulators of metal and metalloid trace elements: facts and fiction. Plant Soil 362:319-334. doi:10.1007/s11104-012-1287-3

van der Ent A, Baker AJM, van Balgooy MMJ, Tjoa A (2013b) Ultramafic nickel laterites in Indonesia (Sulawesi, Halmahera): mining, nickel hyperaccumulators and opportunities for phytomining. $\mathrm{J}$ Geochem Explor 128:72-79

Verbruggen N, Hermans C, Schat H (2009) Molecular mechanisms of metal hyperaccumulation in plants. New Phytol 181:759-776. doi: 10.1111/j.1469-8137.2008.02748.x

Wang H, Tang S-M, Liao X-J, Cao Q-M (2008) Physiological and molecular mechanisms of Mn uptake by hyperaccumulating plant Polygonum hydropiper (Polygonaceae). Acta Bot Yunnanica 30: 489-495

Whiting SN et al (2004) Research priorities for conservation of metallophyte biodiversity and their potential for restoration and site remediation. Restor Ecol 12:106-116. doi:10.1111/j.1061-2971. 2004.00367.x

Xue SG, Chen YX, Reeves RD, Baker AJM, Lin Q, Fernando DR (2004) Manganese uptake and accumulation by the hyperaccumulator plant Phytolacca acinosa Roxb. (Phytolaccaceae). Environ Pollut 131: 393-399

Yang SX, Deng H, Li MS (2008) Manganese uptake and accumulation in a woody hyperaccumulator, Schima superba. Plant Soil Environ 54: $441-446$

Yang QW, Zeng Q, Xiao F, Liu XL, Pan J, He JF, Li ZY (2013) Investigation of manganese tolerance and accumulation of two $\mathrm{Mn}$ hyperaccumulators Phytolacca americana L. and Polygonum hydropiper L. in the real Mn-contaminated soils near a manganese mine. Environ Earth Sci 68:1127-1134. doi:10.1007/s12665-0121814-9

Young SD, Zhang H, Tye AM, Maxted A, Thums C, Thornton I (2005) Characterizing the availability of metals in contaminated soils. I. The solid phase: sequential extraction and isotopic dilution. Soil Use Manag 21:450-458. doi:10.1079/sum2005348

Zhang H, Young SD (2005) Characterizing the availability of metals in contaminated soils. II. The soil solution. Soil Use Manag 21:459467. doi:10.1079/sum 2005349

Zhao FJ, Lombi E, McGrath SP (2003) Assessing the potential for zinc and cadmium phytoremediation with the hyperaccumulator Thlaspi caerulescens. Plant Soil 249:3743. doi:10.1023/a:1022530217289 